\title{
The S-Word: Discourse, Stereotypes, and the American Indian Woman
}

\author{
DEBRA MERSKIN \\ School of Journalism \& Communication, University of Oregon, Eugene, Oregon, USA
}

What's in a name? Plenty when it comes to the ability of words to establish identity. In 2005 in Oregon, for example, 142 land features carried the name "squaw"-Squaw Gulch, Squaw Butte, Squaw Meadows, and Squaw Flat Reservoir (U.S. Geological Survey, 2008). This article examines the term squaw, its presentation in popular culture, and how this framing constructs Native womanhood in the public imagination. Two primary representations are revealed in the discourse defining squaw: as sexual punching bag and as drudge. The opinions and attitudes of reporters, citizens (Indian and non-Indian), government officials, agencies, and tribal representatives are included as reflected in journalistic accounts of the land form debate about the use and meaning of the label squaw. The psychological impact of this racial and sexual slur has a significant negative impact on quality of life, perceptions, and opportunities for Native American women (ethnostress) due to the consistent use and reification of the squaw stereotype through more than 400 years of U.S. history. This article is written as part of a larger body of work that argues for an expansion of Schroeder and Borgerson's (2005, 2008) representational ethics of images to include words.

KEYTERMS advertising, American Indian, discourse, ethnostress, Native American, stereotypes, women

Many thanks to the Center for Women and Society at the University of Oregon, which provided funding to support development of this research. I also want to thank Carolyn Stroman and the anonymous reviewers for their suggestions in refining this article.

Address correspondence to Dr. Debra Merskin, School of Journalism \& Communication, University of Oregon, Eugene, OR 97403. E-mail: dmerskin@uoregon.edu 
On January 1, 2005, in Curry County, Oregon, Squaw Valley Road became Cedar Valley Road. It wasn't the property owner's idea. It was not the idea of the county commissioners. It was the law. In 2001, Oregon legislators passed Senate Bill 488 (Bill, 2001). Although the U.S. federal government does not require renaming of places called squaw, Oregon, which has more sites so named than anywhere else in the nation, does. In September 2007, the U.S. Board of Geographic Names approved removal of the word squaw from eight places in Northern Idaho, three of which are on the Coeur d'Alene Reservation and five outside of the reservation but part of the tribe's traditional lands (Hagengruber, 2006). The "carto-controversy" (Silvern, 2002 , n.d.) request for change came directly from tribal members who found the term offensive. Similar to disputes over racist team mascots, not everyone sees the change as positive or necessary. Opponents of the Idaho change argued, "the colorful history of the Wild West should not be plowed under simply to be polite" (Hagengruber, 2006). Idaho State Representative Dick Harwood (R-St. Maries) opposed the change with an argument remarkably similar to those who argue for the maintenance of racist sports team mascots: "It was an honor. It's how you use the word, not what the word means" (as cited in Hagengruber, 2006).

To many Native people, ${ }^{1}$ renaming is not just a matter of politeness, it is an effort to reclaim indigenous identity and decolonize the landscape. In this case, the tribe wants the name squaw changed to reflect positive female role models. For example, in the St. Joe National Forest, the tribe proposed renaming Squaw Creek Chimeash Creek, which roughly translates to "young woman of good character." Cody McDonald, a Judith Basin (Montana) County commissioner said, "When these things were named a hundred years ago, they didn't mean to offend anybody .... And it's a waste of time. Everybody's still going to call it 'Squaw Coulee'" (Bello, 2008, p. 1A). Even if no longer consciously connected to its etymology, Navaho Times publisher and editor Tom Arviso, Jr. (n.d.) stated, "The most offensive term used to address Native American women is 'squaw.",

This paper explores the term squaw as an element of discourse that frames a version of indigenous female-ness consistent with the historical colonial construct of stereotypes of American Indians in general as animalistic, savage, and sub-human. The emphasis is on "representational ethics-who has the right to represent others and under what circumstances" (Johnston, 2000, p. 73). It is written in the same spirit as d'Errico's (2005, p. 2) discussion about hyphenated Americans, as a "provocation toward the deconstruction of definitions which have trapped indigenous peoples in the dreams of others." A feminist lens is used to look into discursive and popular culture uses of "squaw," motivated by the naming controversy, as catalyzed by state legislation mandating changes in place names.

Furthermore, this article explores the way mass media constructed, sustained, and disseminated squaw stereotypes impact the lives of indigenous, 
Native North American women. In the media, these representations not only reinforce dehumanizing and limiting views of the capabilities of Native women to themselves (internalized oppression) and to non-Indians, but also result in "structural exclusions and cultural imagining [that] leave[s] minority members vulnerable to a system of violence" symbolically and actually (Perry, 2002, p. 232). Drawing on Butler, "the performative construction of reality rests heavily on discursive acts, i.e., on the power of naming and speech to define reality" (Nagel, 2000, p. 116). Therefore, this deconstructive approach takes its examples from the past, recognizing that squaw is still with us. "Deconstruction is thus an attempt not simply to reverse certain categories but to displace, dislocate, or to shift (if ever so slightly and slowly) a historical structure and the logical system that has served as a convenient excuse for it" (Vannoy Adams, 1985, p. 26)

By describing the persistence, pervasiveness, and perpetuation of the use of squaw in public discourse, I extend Schroeder and Borgerson's (2005, 2008) model of representational ethics of images to include words and Delgado and Stefancic's (2001) critical race theory to explore the following questions: How is the word squaw characterized in the contemporary popular imagination? What are the implications of this stereotype for Native women?

The squaw stereotype is visible in three synergistic categories, the first two of which are used as an organizing tool for this article: (a) as a label in novels, histories, television programs, and films; (b) as an assigned name for roads, creeks, buttes, and peaks; and (c) as an iconic image in photographs, art, and advertising. Space limitations prohibit an extensive examination of the many examples of the squaw stereotype; therefore, illustrative examples are used. Together these cultural expressions, presented through images and words of White society, reinforce public impressions of what constitutes female Indian-ness and the place of indigenous women in a simultaneously romanticized and demonized past. These media-generated and sustained stereotypes support Perry's (2002, p. 3) description of "faces of oppression" (exploitation, marginalization, powerlessness, cultural imperialism, and violence) as applied to Native Americans.

In the following sections I address the historical origins of the term squaw, followed by a discussion of the construction of the squaw stereotype, the power of language to frame lived experience, and a discussion of the episteme and the concept of representational ethics. Finally, the article concludes with the phenomenological implications of the squaw stereotype in terms of the physical and psychological health-related consequences of living with the weight ethnostress, defined as internalized oppression resulting from negative verbal and visual discourse that results in poor self image, low self esteem, and dissociation which have very real health consequences (Cajete, 1994; La Duke, 1999, 2005; McBride, 2003; Pflüg, 1996; Sanchez, 2003). Examples from historical literature as well as contemporary studies of squaw in media are included. 


\section{THE S-WORD}

A Google search of the term squaw yields more than 4.8 million hits. Some of these are discussions of the word, its etymology, and appropriateness (or lack thereof), but most are links to resorts, casinos, or about landforms. The etymology of "squaw" is complex and contested. It appears to be one among a number of Eastern Algonquian words appropriated by English and French explorers during the early contact period in American history. Around 1634, the term shows up in historical documents and literature in the Eastern US. Some say the word meant "young woman" (Massachusett), other say "woman," or "an Indian woman or wife" (Jonas, 2003). The Oxford English Dictionary (1989), at its first level of definition, only says squaw to be "A North American Indian woman or wife." But the entry also indicates this use is rare.

E. Sanders (2004, p. A12) states the term "squaw ... turned into a slur on the tongues of white settlers, who used it to refer derisively to Indian women in general or a part of their anatomy in particular." This is evident in an 1890 quote by Welcker (as cited in Oxford English Dictionary, 1989) in Tales West: "By way of expressing their utter contempt for him they called him a 'squaw'." According to Stubben and Sokolow (2005, p. 89), squaw "is a synonym for prostitute, harlot, hussy, and floozy." Note that in Algonquin and Mohawk languages, the word squaw means vagina or female genitalia. The word has different meanings or may not exist at all in hundreds of other Native American Indian languages. According to Mihesuah (2003, p. 102), "the 'squaw' is the dirty, subservient, and abused tribal female who is also haggard, violent, and eager to torture tribal captives." Neutrality, however, exists only in the minds of the bestowers:

That curious concept of 'squaw,' the enslaved, demeaned, voiceless child bearer, existed and exists only in the mind of the non-Native American and is probably a French corruption of the Iroquois word otsiskwa meaning 'female sexual parts', a word almost clinical both denotatively and connotatively. The corruption suggests nothing about the Native American's attitude toward women; it does indicate the wasichu's view of Native American women in particular if not all women in general. (Sanders \& Peek, 1973, p. 184)

Regardless of its ancient origins, squaw has come to mean something quite different. In 1992 Suzan Harjo (Mohawk) appeared on The Oprah Winfrey Show and brought wide awareness to this inflammatory and racist word:

The word 'squaw' is an Algonquin [sic] Indian word meaning vagina, and that'll give you an idea of what the French and British fur trappers were calling all Indian women, and I hope no one ever uses that term again. (Cited in Adams, 2000). 


\section{STICKS AND STONES}

Language constructs knowledge and knowledge is power, according to theorists, philosophers, and scholars. The words we choose to use help construct social, cultural, economic, and historical reality. Thus, "discourses of domination" put language to the social use of defining and oppressing those constructed as other (Henry \& Tator, 2002, p. 13).

Drawing on Bakhtin, language is never neutral, and the choice of particular words and phrases works to articulate an individual's beliefs operating as a form of disclosure. For Bakhtin (1973), language is ideological and dialogic - we speak out of bounded systems of constructed knowing and every utterance is a "two-sided act" (p. 9). This means that a word is chosen specifically for its shared territory between sender and receiver - it is both ideological and social. As a manner of questioning words and the power structures behind them, discourse analysis provides a mechanism through which message and motivation are revealed. Typically, it is used to address the context and foundations for the assumptions contained within it. Political discourse and speechmaking are, for example, intended to persuade citizens to vote for a particular candidate or think about an issue in a particular way. Importantly, linguistic patterns in discourse are contextualized as part of what has come to be called a "cultural turn" constituted by exploring a culture through its own mechanisms, such as speech patterns, use of symbols, or nonverbal signals. In addition, forces outside of a particular culture can influence those within it, such as economics, policies, and politics. Thus, discourse analysis of "talk and texts" also includes a discussion of the consequences of particular word choices (McKinlay \& Potter, 1987, p. 443). Foucault, for example, examined how power "installs itself and produces real material effects," evidenced by its preponderance in institutions and in everyday life (as cited in McHoul \& Grace, 1997, p. 22).

Thus, as an analytic topic, a post-structuralist view of discourse carries with it the idea that "language embodies the 'sediment' of social practices which undermine its use as a neutral descriptive medium" (McKinlay \& Potter, 1987, p. 444). Simply put, language is loaded with political and emotional motivations. Through "ideological racialization" language is imbued with racialized meanings (Henry \& Tator, 2002, p. 11), thus constructing and inferiorizing specific individuals or groups of people. Therefore, according to Foucault (1980, p. 131), whether or not the meaning behind a word is true or false is less important than whether or not it functions and is effective in "organizing and regulating relations of power."

Naming and/or re-naming landforms, removing what indigenous people of an area called a place, is a form of colonization. Watner and McElroy (2004, p. 27) call it the "hegemonic project," when "native names for flora, fauna, insects, mountains, valleys, birds were effaced and replaced 
by the nouns and taxonomies of the conquerors." Re-labeling in the language of oppressor, thus not only appropriates the person, place, or thing but also transfers power for the oversight, management, and control. Giving land, taking away land, giving names, and taking away names are all forms of colonization. In 1897, the Superintendent of the U.S. Boarding School for Crow Indians in Montana, Frank Terry, described government policy in an essay "Naming the Indians": "The command to give names to the Indians and to establish the same as far as possible by continuous use has been a part of the 'Rules and Regulations' for years past' (p. 301). Terry then cited this letter from the U.S. Department of the Interior:

In this thing, as in nearly all others, the Indians do not know what is best for them. They can't see that our system has any advantages over their own, and they have fought stubbornly against the innovation. (p. 302)

In Christian mythology, at the moment God gave Adam the power to name the animals, the animals no longer belonged to themselves and, once categorized, as members of groups were no longer individuals. Similarly, labels drawn from the colonizer's worldview named Indians as Indians. Anglo names were applied to tribes, and decisions about what words were or were not offensive came from the European perspective. Akin to controversies over offensiveness (or not) of sports team mascots such as the Atlanta Braves or the Washington Redskins, which words are problematic are also in the eyes and ears of the beholder. Stereotypes about people operate in the same way. In the absence of an opportunity for self-definition, words, regardless of their ancestry, are assigned as names for peaks, mountains, roads, creeks, and buttes.

\section{PLACES AND PEOPLE}

In Maine, the use of squaw is prohibited under all circumstances, and yet, the small town of Stockton Springs, near the Penobscot Nation, refused to change place names and road signs. In Idaho, a famous ski resort is called Squaw Valley. Arizona has Squaw Tit Peak. According to Monmonier (2006), there are 785 official squaw toponyms in the United States, most which are in the Pacific and Rocky Mountain states. Oregon has the most with 323 "squaw names per 100,000," followed by Idaho (p. 53). "Although it has yet to rival nigger in 'out-loud' offensiveness, squaw clearly upstages Negro as the thorniest issue in applied toponymy" (p. 52).

The problem with racist names of landforms came to wide public and government attention in the 1990s when Native activists organized and lobbied governments to force change on the grounds that, from an Indian point of view, the word was offensive. Unlike other racial and ethnic groups who 
have had numbers and political clout to change many, and in some cases, most of stereotypical representations of themselves (such as African Americans), Native Americans, when seen at all, are still viewed as one-dimensional forms, "They are America's racial Other and alter ego: rejected in order to justify the violent treatment of them as part of progress and civilization, yet also desired for the freedom, land, and innocent state they represent" (Marubbio, 2006, p. 4). Monmonier (2006, p. 2), argued the term alone may not be the most problematic, but rather that it is particularly objectionable because it "seems more deeply rooted in the white majority's often-brutal treatment of indigenous North Americans." It is both content and context that matters. While writers such as Monmonier (2006, p. 52) argue that the term came to attention "from relative obscurity" once again, that depends on whom you ask. Whether or not squaw is offensive depends on one's angle of repose:

We've been degraded for 500 years and to the general public they're walking around thinking that they did something great by naming a creek or a river Squaw. It stings a little. It'd be like if a shopping mall were called Holocaust Mall. We're not angry, we know what it means. But we have to educate the general public first. (Buffalo, as cited in Norden, 1996, p. 5)

\section{REPRESENTATIONAL ETHICS}

Ethics is as slippery term as there ever was. It is not the focus of this article to wrestle with its many modes. Instead, I adopt Schroeder and Borgerson's (2005, p. 579) concept of representational ethics and identity that says, "represented identities profess to express something true or essential about those represented." A representational ethics of images requires inquiry into and an understanding of "not only the implications or consequences of representational conventions-customary ways of depicting products, people, and identities . . . but also emphasizes the ethical context from which such representational conventions emerge" (p. 580).

Schroeder and Borgerson (2008) state marketers have a responsibility to produce ethical messages, thus they need not only to acknowledge how media messages operate as conduits to consumers, but also that marketing is a representational system that produces meaning outside the realm of the promoted product or service. They suggest, rather than applying the typical critiques of capitalist, consumerist society or morally evaluating representations of individuals and/or groups, that an ethics of representation is needed and that it is done from an identity perspective. That is, "represented identities profess to express something true or essential about those represented" (p. 93). This model involves not only an eye to implications 
and consequences of "representational conventions - customary ways of depicting products, people and identities," but also "the ethical context from which such representational conventions emerge" (p. 88).

Over time, representational conventions, as discussed in the following section, become a kind of "visual truth," or "authentic knowledge derived by seeing" (Newton, 2000, p. 8). These practices construct and maintain particular types or categories that, left unchallenged, endure, and have "the weight of established facts" behind them (Gordon, 1995, p. 203). Ordinarily created through the eyes of those in societal positions of power, these representational practices "affect some people's morally significant perceptions of and interactions with people, and if they contribute to those perceptions or interactions going seriously wrong, these activities have a bearing on fundamental ethical questions" (Walker, 1998, p. 179), Thus, if media representations cater to the interests of dominant society in maintaining suppression of a group for the gain of the other, they are unethical.

\section{DEFINING INDIAN-NESS}

Whereas "Little Black Sambo" tales reinforced the construction of racist beliefs about Blacks, songs such as "Ten Little Indians" or "Cowboy and Indian" games similarly framed Indian otherness in the White mind. Moreover, "the essence of the White image of the Indian has been the definition of American Indians in fact and in fancy as a separate and single other. Whether evaluated as noble or ignoble, whether seen as exotic or downgraded, the Indian as image was always alien to White" (Berkhofer, 1979, p. Xv). Context is key. Anti-Indian sentiments did not begin solely with the subjugation and dislocation efforts of the 1800s. Rather, three major economic, social, and political movements or "fateful encounters" (Goings, 1994 , p. 332) mark points in time when the "West encountered" Indian people, "giving rise to an avalanche of popular representations based on the marking of racial difference": (a) 15th century contact between European traders and explorers and the contamination and conquest of indigenous peoples on the North American continent; (b) European colonization of the Americas and the scramble for control of territories, markets, and raw materials; (c) pre- and post Civil War migrations from the eastern United States to the West.

Thus, the wide array of individual qualities, experiences, histories, and characteristics are truncated by stereotyping into a single Pan-Indian identity based on a unilateral conception of "Indianness" (Merskin, 2001, p. 159). Consistently repeated representations have power as "these are the ideas we have been hearing for a long time and that we've ended up believing out of truth, custom, or repetition" (Dávila, 2001, p. 56). No other Native American stereotype has been framed as consistently and tenaciously as that 
of the Indian princess (female noble savage) and the squaw (Bird, 1999; Kessler, 1996). Scholarly analysis of representations of Native American people has focused primarily on Natives as a group and, in the few studies that break portrayals out by gender; the emphasis is on men (Bird, 1999). This includes "literary lore" in which "there is no sense of the part that women have played in tribal life either in the past or today" (Gunn Allen, 1986, p. 263). Bird's path breaking article described the sexualization and desexualization of Native American men and women in relation to the White gaze, arguing this is a form of colonization.

The two most common stereotypes of Indian women are the Indian princess, who conveys natural, wholesome, virginity, and freshness, and the Squaw/drudge, her opposite (Green, 1975; Green, 1993; Kessler, 1996; Valaskakis; 2005; Marubbio, 2006), the "failed" princess, "who is lower than a bad White woman" (Bird, 1999, p. 73). The squaw is the "darker twin" of Pocahontas (Valaskakis, 2005, p. 134), and the "anti-Pocahontas," according to Francis (1995, pp. 121-122):

Where the princess was beautiful, the squaw was ugly, even deformed. Where the princess was virtuous, the squaw was debased, immoral, a sexual convenience. Where the princess was proud, the squaw lived a squalid life of servile toil, mistreated by her men - and openly available to non-Native men.

\section{THE IMAGINED INDIAN WOMAN}

Some of the earliest stereotyping of Native people in general, and Native women in particular, is found in "sermons, histories, and captivity narratives" (Kessler, 1996, p. 18), where the unruly savage is redeemed/civilized into the noble version. Two forms of squaw representations emerge: squaw as sexual punching bag and squaw as drudge. Historically, most Whites assumed that all Indians were inferior - ignorant degraded savages and heathens - and furthermore, that the men, who regarded them as slaves, "beasts of burden," mistreated the women forced to do all the tedious drudgery while the lazy men ruled over them. Even if the Indian woman was not sexually loose by choice, she was victimized by polygyny, or her sexual favors could be bought, sold, or given away by male relatives. Such assumptions then reinforced a widespread perception that only Christianity raised women to a position of honor and respect (Lindley, 1996, p. 148). Smits (2007, p. 27) argued that the "squaw drudge" and "her work-shirking Indian husband were based on Euro-American misconceptions, ethnocentrism, and particularly on whites' deeply felt need to rationalize their budding hegemony in America." Thus, "abominably slothful" husbands who mistreated women became one definition of "savagism" (p. 27). 
According to Smits (2007, p. 29), 17th-century English men initiated the "distorted images of 'squaw drudges' and indolent braves." Despite a quite different lived reality, Captain John Smith, who became the husband of 12-14-year-old Pocahontas, described Native gendered work relations for women as "the women be verie painefull [industrious] and the men often idle" (p. 29). Native women and men were "put in their place" by White commentators and writers who, "through three centuries of relations ... persisted in citing the drudgery of Indian women and the indolence of Indian men as proof of savagism.

By the 19th century, Indian women and men had been transformed into negative reference groups representing exact counter images of EuroAmericans' ideal sexual statuses and roles" (Smits, 2007, p. 29). High profile expeditions such as Lewis and Clark's gave credit to, and some say took advantage of, an Indian woman, Sacagawea, without ever recording her likeness.

Working to reinforce this vision, 18th-and 19th-century sculpture, paintings, novels, and sheet music also carried the symbolic stereotypical savage. Grade and high school text books, when they mention indigenous people at all, have taught this same information contributing to a consensus view of Native (in) ability and (in) visibility. Teacher Debbie Reese (Nambe Pueblo), asked "what role might the use of the word in children's historical fiction play in the way that teacher responded to the Native woman?" Reese (2007) examined the way The Sign of the Beaver by Newberry award winning, non-Native author Elizabeth George Speare (1983), presents Indian women as an example. The story is about a White boy named Matt, who never uses the term squaw. However, the word is used eight times by Native characters. Women's work is pejoratively described as "squaw work" (p. 52, 100, and 124), and a Native girl referring to a Native boy Attean as someone who "think squaw girl not good for much" (p. 97). Reese (2007) said,

I doubt that Attean would have the sentiments he has about women, especially women who are his elders. I don't think he would be scornful of them. Moreover, I don't think he would use the word "squaw" at all. If we were considering accuracy of his speech, he'd probably use the word his people would use for women in their language.

Advertisements and product labels such as Squaw brand sifted peas and Siwash Squaw apples presented the Squaw stereotype and associated her with the land and labor. In "buckskin rippers" (romance novels; Hernández-Avila, 2005, p. 208), Indian women are discarded not only by White men but also by Indian men. For example, in the fictional romance (allegedly by model Fabio) Comanche (p. 54 as cited in Bird), the heroine describes how once an Indian man sees a White woman, he is done with her: "Agnes had disappeared to become another faceless squaw and breeder 
among the People." In The Making of Sacagawea, Kessler (1996, p. 22) traced the squaw stereotype to captivity narratives, which represented her as

no more than slave to their families in you and to their husbands after marriage. Dragging and dressing meat, bearing children in the woods by themselves, and suffering the blows of men, these women have been portrayed, in some cases, as the victims of savage culture that could never comprehend the elevated treatment females deserve.

This narrative satisfied dominant culture's need for proof of Indian's inability to assimilate. The squaw, "defined as the perpetrator of heathen viciousness," was used as justification for the elimination not only of the male "savage," but also the female, in order to create safe passage for so-called "civilized" White Europeans (Kessler, 1996, p. 22). Emblematic of manifest destiny, the squaw symbol signified both the past and the obstructions to the future, scapegoat, and rebel. The representation of female Indians was "complicated through her gender and sexuality. Her gender makes her a target for rape, while her death ensures the end of a generation" (Marubbio, 2006, p. 4). "The female Indian drudge figure, notable for her many children and haggard body, and the wanton squaw-capitalize on the Native woman's supposed promiscuity and suggest the ramifications of sexual aggression and savageness" (p. 12)

In an autobiography of the 1850s, General George Crook noted, "it was not unfrequent occurrence for an Indian to be shot down in cold blood or a squaw to be raped by some brute." Punishment of the White men as, it seems, "unheard of" (as cited in del Mar, 1996, p. 28). Furthermore, according to another source, in 1857 among the lower Rogue Indians at the Siletz agency in Oregon, William Choate described how his two companions, upon seeing Indian women on the beach, said "they were going to screw the squaws" ([italics original], as cited in del Mar, 1996, p. 28).

Probably Sundquist, who examined 134 Indigenous women characters from "American imaginative literature poems, plays, short stories, and novels," wrote the most comprehensive study of the representations of Indian women in print media between 1799 and 1911. Although the majority of characters were men, with characteristics such as "iron constitution, superior physique, proficiency in wilderness skills, stoicism, and a special way of speaking," Indian women were absent these positive qualities. White women wore the shawl of virtue and goodness whereas Native women were variously categorized as "the Drudge, the Fury, and the Witch" (Sundquist, 1987 , p. 13). The two most famous Native women portrayed in popular media are Sacagawea and Pocahontas, both of whom are presented as sexualized Indian Princess types. Despite there being no visual representations of the first and few of the later, that hasn't inhibited artists, writers, and 
authors from creating them according to their own ideas of female Indianness within the cultural context of the day.

Monmonier (2006, p. 2) argues that the meaning of squaw was "sanitized...for filmgoers" by Hollywood, "in a typical shoot-em-up Western the dumpy, silent squaw acts like little more than her husband's property." According to Marubbio (2006, p. 49), "over a seventeen-year period, 1914-1931, the Squaw Man films," of Cecil B. De Mille, "promoted classist and nationalist themes of supremacy and anti miscegenation mingled with an imperialist nostalgia for the Native American and the frontier American West." In the 1914, 1918, and 1931 versions of the Squaw Man films, the White male hero marries the Indian squaw, "their themes of interracial marriage reflect concerns about cultural difference, miscegenation, and interracial families" (p. 30). According to Smith (2000, p. 116), "it would be hard to over emphasize the importance of the 'squaw-man' story to early American cinema. Filmmakers retold the story hundreds of times, and it was the dominant plot of the Indian western genre." Constantly risking the wrath of White cowboys, the miscegenation in these films functioned as a morality tale of warning to anti-miscegenation, which "emerges as the primary source of danger to white society" (Marubbio, 2006, p. 42)

Similar to the "sacrificing senorita" Latina stereotype (Keller, 1994; Merskin, 2008), the squaw character willingly gives her life in order for the White man to achieve his goals. "The Squaw at once realizes the situation. She must, for her love for him, make the sacrifice which she does by sending a bullet through her brain, thus leaving the way clear for him-a woman's devotion for the man she loves." For example, in The Kentuckian, the plot reveals that the White lead character must return to his White roots in the East and cannot take his squaw wife with him, rather than pose "a hindrance to his status in white society" (Marubbio, 2006, p. 45). Thus, the Indian woman is erased, expendable, and an object. Similarly, in the 1956 film Mohawk (Neumann, 1956), the story line read,

Reckless painter Jonathan Adams (Scott Brady) is sent into Indian country where he finds love and danger among a warrior tribe. When he falls for Onida, a native Iroquois girl, Adams makes his two deadly enemies-his spurned fiancée Great (Allison Hayes) and the squaw's jealous lover. Torn between his love for Onida and his patriotic duty, Jonathan must battle both bloodthirsty natives and corrupt ranchers in his pursuit of justice.

References to Indian women as squaws exist not only in the distant past. In the 1976 movie The Outlaw Josey Wales (Eastwood \& Kaufman, 1976), Clint Eastwood plays a Missouri farmer who seeks revenge on an outlaw band of Union Army soldiers who killed his family. Along the way, he picks up a rag-tag band of people (and a dog) including a stereotypical old Indian chief and a "talkative Indian 'squaw", who refuses to leave him (imdb.com, 2008). In the 1980 film Mountain Men (Lang, 1980), staring Charlton Heston 
and Brian Keith, the video box described the plot as "A pair of grizzled frontiersmen fight Indians, guzzle liquor, and steal squaws in their search for a legendary valley 'so full of beaver that they jump right into your traps' in this fanciful adventure" (imdb.com).

As Smits (2007, p. 28) noted, representations of the drudge squaw and good for nothing-lazy husband, persisted into the 19th century, by which time the stereotypes were fully reified. The "genteel 'lady of leisure,' who came to personify Euro-American civilizations highest attainments, was smugly contrasted with the lowly 'squaw drudge,' the symbol of unregenerate savagism." In a second study, Sundquist (1991) examined content of literary works from 1911-1980 revealing 165 female Indian characters. appearance was the most often mentioned trait by the 85 authors works studied and five categories of indian woman: sibyls and witches, sirens and furies, angels/victims, mothers and drudges, and others (which included comics, identity problems, and victims of accidents). mothers was the largest of the categories represented (46 characters) and contains the subcategories of earth mothers, terrible mothers, good mothers, and "drudges," the one most similar to squaw. The earth and good mother categories contain the few positive traits of Indian women, although these are often used in ways that demonstrate a lack of intelligence or judgment because of being so self-less or loyal. These women are "good and kind, meek and self-effacing," she can be "young, middle-aged, or old... self-sacrificing, self-abnegating" (p. 109). The terrible mother is "domineering, clinging, and possessive ... so so wrapped up in her children that she lives only for them. The result for the children is often disastrous" (p. 104). She is terrible because she is destructive, divisive, and a nag. The drudge, "can be defined as a person who must work hard and long at unpleasant tasks ... was treated like a drudge by her man... she was expected to work herself almost to death while her husband was lounging about, issuing sharp orders as if to a domestic animal" (p. 88). She often has many children and may survive several husbands. Her appearance can be scary or comical. Sundquist (1991, p. 134) described the drudge as "Working hard both in the wigwam/lodge etc. and in the fields, often from dawn to dusk", and having "a miserable life, as they are married to tyrants who treat them cruelly and callously," and "completely helpless victims of their husbands' ruthless natures." In films in particular, in the early 20th century, Native women's double otherness is also evident. Kessler (1996, p. 148) noted, in 100 films that depicted Natives between 1970 and 1984, only $28 \%$ featured an Indian woman.

\section{STATE OF NATIVE WOMANHOOD}

It has been well established that women are generally absent, underrepresented, or misrepresented in nearly all media content (Gallagher, 
2001, 2006; McRobbie, 1997; Tuchman, 1978). This is especially the case for indigenous women who are not viewed as members of mainstream (i.e., White) society (Bird, 1999; Green, 1975; Merskin, 2001). Cultural and media sustained stereotypes of Native women (of which squaw is one of the most damaging and pervasive) effect access to resources and opportunities for girls and women. They also influence self-esteem as well as hopes for the future. Representations of Native women in the media and the everyday effects of stereotypic thinking on the social, legal, cultural, and economic aspects of public policy has received negligible attention from researchers, scholars, and policy makers. One of the characteristics of oppression is lack-lack of the same level and quality of health care, political access, legal equity, and power that the dominant culture enjoys. Native Americans share with African Americans, Latino/as, and Asian Americans disproportionate number of diseases particular to a life of stress, poverty, and shame. Native women bare the burden of "ethno-stress," which is defined as follows:

A psychological response pattern stemming from the disruption of deeply held cultural life and belief systems that one cares about deeply. Such a disruption may be abrupt or occur over time and generations. Its initial effects are readily visible, but its long-term effects are many and varied, usually affecting self-image and an understanding of one's place in the world. (Cajete, 1994, p. 189)

Winona La Duke (2005), quotes colleague Agnes Williams, who described the experience of ethnostress as follows:

In other words, you will wake up in the morning, and someone will be trying to steal your land, your legal rights, your sister will be in jail, your public Anglo-dominated school district will be calling about your children's conflicts with teachers or their spotty attendance, and your non-profit organization's funding is getting cut by a foundation because you are no longer a priority (p. xvii).

Native women are considered to be of the fourth world, meaning, "situations in which a minority indigenous population exists in a nation wherein institutionalized power and privilege are held by a colonizing, subordinating majority" (Walters \& Simoni, 2002, p. 520). Despite hurt feelings and negative self-image, particularly among young Native women, "stereotypes actually drive their distressing legal and societal treatments" (Bender, 2003, p. I). Contemporary examples of subordination and oppression include disparities in health care, economic and legal inequities, and health consequences of discrimination. For example, American Indian women have lower social and economic status than White women with lower earnings ( 58 cents on every dollar White men make), less education, more poverty (25\%), more than a third $(38 \%)$ of families headed by a Native woman are in poverty and 
receive poor quality health care (Caiazza, Shaw, \& Werschkul, 2004). Native American girls are "two to three times more likely to commit suicide and...twice as likely as other Americans to die before the age of 24" (Clarren, 2009, p. 6). Furthermore, the AIDS case rate in American Indian/ Alaska Native women is almost four times the rate for non-Hispanic White women (Centers for Disease Control \& Prevention, 2000). "Native women are disproportionately affected by violence at a rate almost $50 \%$ higher than that reported for African American males" (Walters \& Simoni, 2002, p. 520).

American Indian/Alaska Native women have the lowest incidence of breast cancer yet have the poorest five-year survival rates ("The unequal burden," 1999); suffer from the second highest rate of being overweight, placing them at a higher risk for diabetes (Ross, 2000); have the highest prevalence of cigarette smoking (40.8\%) compared with any other ethnic group ("Cigarette smoking," 2001, p. 869); and are more likely than White women to be alcoholics (therefore experience disproportionately high rates of chronic liver disease and cirrhosis) (Ross, 2000). In addition, Native American women are "ten times more likely to likely be killed in a violent death than are white women" (La Duke, 2005, p. xviii). Homicide is the 9th leading cause of death of Native women. Along with African American women, Native women are at the highest risk of intimate partner homicide (Tessier, 2008; Guedel, 2009). Thus, Native girls and women live on the periphery of mainstream and, at times, Native society. They are simultaneously marked as racial and sexual other.

'Ethno-stress' is the reality of our situation as Native women, which is directly related to the process of colonization, sexual violence, dehumanization and marginalizing of who we are. The reality is that what is personal an intimate-whether your family history, the perceptions of you as an individual, or perceptions of your daughters-become the centerpiece of power relations between people and societies. (La Duke, 2005, p. Xviii).

\section{CONCLUSION}

Conceptually, this article extends W.E.B. Du Bois's (1903/2005) concept of "double consciousness," which is a "sense of always looking at oneself through the eyes of others, of measuring one's soul by the tape of a world that looks on in amused contempt and pity" (p. 3). Du Bois said, as an American and an African American, he was a "two-ness" with "two souls, two thoughts, two unreconciled stirrings; two warring ideals in one dark body" (p. 3). I suggest Native American women face a "four-ness" or a double, "double consciousness" with each identity demanding a shift, of American, that of other (Indian), as woman, and as member of a tribe. These are images (re)presented, re(inforced), and repeated in the content of mass 
media and popular culture. Embedding racist and sexist stereotypes in brands, labels, landforms, and media images and words is an exercise in power.

I argue that the persistent use of the stereotypical squaw is far from harmless. Rather, that messages conveyed through the authority of mass media (broadly defined to include print and broadcast journalism, advertising, and photojournalism) and popular culture rigidify and perpetuate the stereotype in American popular imagination reifying the hierarchical position of dominant Euro-American culture by controlling access to resources and power. A woman might recognize the word squaw as something from the past, and yet the pain of it having been used against still burns. Thus, "the individual is both the site and subject of these discursive struggles for identity and for remaking memory" (Richardson \& Adams St. Pierre, 2000, p. 962).

Stereotypes, as hegemonic tools, reduce individuals to a single, monolithic, one-dimensional types that appear and are presented as natural and normal, as "regimes of truth" (Coombes, 1998, p. 190) as they fit into ideological patterns of representations that serve, among other functions, to establish "in-group categorizations of out-groups" (Ramíerez-Berg, 1990, p. 294). This expression is written on the bodies, minds, and hearts of Indian and non-Indian people. Freire (1970, p. 40) convincingly argued that an oppressive situation is one "in which ' $\mathrm{A}$ ' objectively exploits ' $\mathrm{B}$ ' or hinders his pursuit of self-affirmation as a responsible person." In reality and symbolically Native Americans are palimpsest, "a textual body effaced, erased, and written over" that evokes "images of violent silencing" (Marubbio, 2006, p. 25). This metaphor reveals repression, ambivalence, uncertainty, and complexity of representations of Natives in general and Native women in particular. Name-calling is established in the psychological literature as harmful, humiliating, and has lasting effects on self-esteem (Delgado, 1982; Seals \& Young, 2003; Devine, 2008). "Being called names contributes to identification with the oppressor and results in an internalized oppression that leads to self-hatred and an ability to function as a whole and healthy individual with a tribal or Native American identity" (Tafoya, 2005, p. 305). Ethnostress, a potential effect of the repetition of negative discourse in the culture, has significant psycho-physiological consequences for identity formation and self-esteem for all Native Americans and for children in particular (Sanchez, 2003). Views of the S-word as non-problematic, as nothing more than a historical artifact, dismiss Indian women's concerns and silence their voices.

Under a system of hegemony, in which ideas serve to create and maintain system of dominance through consent of the oppressed, words, and images do the ideological dichotomous work of identifying who is one of us and who is one of them. I argue the mass media have symbolically colluded with societal, cultural, and economic injunctions against Native American women's participation in American life. The construction of the 
squaw other is a form of what Dyer (1993, p. 98) called "media fiction" that is coded in ways consistent with White, racist, heteronormative cultural texts. They are tendencies in mass media for economic, dynamic, efficient, finished-qualities, particularly when popularized in the form of translator and servant. The persistence and ubiquity of this image speaks to expansionist mythology that still exists. "Frontier myths, which have embraced and illustrated concepts of manifest destiny, did not just shape attitudes and actions in the past; they have continued to inform present problems in America" (Kessler, 1996, p. 13).

Furthermore, racist and sexist stereotypes, while primarily impacting the lives of those (mis)represented, also influence others as well. As Stubben and Sikolow (2005, p. 89) reminded us, "The term squaw is not only derogatory toward Native American women, it is derogatory toward all women."

As a media effect, stereotyping is an ethical problem. A representational ethics, as advanced by Schroeder and Borgerson (2005, p. 595), argues that when identity is used to sell, and I add whether that is verbally or visually, as information or advertisement, they "purport to express something true or essential about those represented" and this allows for a culture's underlying ideology to emerge. Many media organizations argue they are working toward increased diversity in content and in employment. Along with this is the responsibility to know something about the people (re)presented and hired. While stereotypes did not originate with marketing and mass media, as evidenced by the brief history on Indians and American culture, communicators should be held accountable for those times when they preserve and perpetuate them.

Despite what popular culture and media portray (Merskin, 1998, 2001), American Indian culture has changed (Sanchez, 2003). Thus, with increased awareness of a people's past and present, as a representational ethics of care, scholars and practitioners are obligated to challenge limiting word and image choices in media and marketing content as moral responsibility. What is or is not problematic should always be considered from the perspective of those represented.

This study contributes to communication research and theory by shinning a light on the power a single word can have in framing reality and how it can contribute to the maintenance of hierarchical power relations. In the case of the S-word, more than two centuries of the word's use suggest to some (usually not Native American women) that its negative energy has expired. To others, however, the very everydayness of the term speaks to its problematic nature as an ideological frame. As has been the case with the N-word, understanding this power and deconstructing its applications can help both researchers and consumers of media information engage with language and images in ways that are more ethical and compassionate. 


\section{NOTE}

1. The terms Indian, Native American, Indigenous North American, and Native are used interchangeably throughout this manuscript taking into consideration the variety of individual preferences.

\section{REFERENCES}

Adams, C. (2000, March 17). Is 'squaw' an obscene insult? The Straight Dope. Retrieved May 10, 2008, from http://www.straightdope.com/columns/000317.html

Arviso, T., Jr. (n.d.). Watch your language. Society of Professional Journalists, Diversity Toolbox. Retrieved May 10, 2007, from http://www.spj.org/dtb7.asp

Bakhtin, M. (1973). Marxism and the philosophy of language (L. Matejka and I. R. Tutunik, Trans.). New York: Seminar Press.

Bello, M. (2008, April 30). Pressure mounts to drop 'squaw' from place names. USA Today, p. 1A.

Bender, S. (2003). Gringos and greasers: Latinos, law, and the American imagination. New York: NYU Press.

Berkhofer, R., Jr. (1979). The white man's Indian: Images of the American Indian from Columbus to the present. New York: Vintage Books.

Bill Prohibiting Use of Term. (2001). Retrieved July 8, 2008, from http://www.leg. state.or.us/brown/pr5_31.htm

Bird, S. E. (1999). Gendered construction of the American Indian in popular media. Journal of Communication, 49(3), 61-83.

Caiazza, A., Shaw, A., \& Werschkul, M. (2004). Women's economic status in the states: Wide disparities by race, ethnicity, and region. Washington, DC: Institute for Women's Policy Research.

Cajete, G. (1994). Look to the mountain: An ecology of indigenous education. Durango, CO: Kivaki Press.

Centers for Disease Control, \& Prevention. (2000). HIV/AIDS surveillance report (Vol. 12, No. 2). Atlanta: Author.

Cigarette smoking among adults-United States. (2001, October 12). Morbidity and Mortality Weekly Report, 50(40). Atlanta, GA: Center for Disease Control.

Clarren, R. (2009, May 25). Paddling toward shore. High Country News, 6-7.

Coombes, R. J. (1998). The cultural life of intellectual properties: Authorship, appropriation, and the law. Durham, NC: Duke University Press.

Dávila, A. M. (2001). Latinos Inc. The marketing and making of a people. Berkeley, CA: University of California Press.

d'Errico, P. (2005). Native American studies: A note on names. Peter d'Errico's law page. Retrieved March 26, 2006, from http://www.umass.edu/legal/derrico/ name.html

del Mar, D. P. (1996). What trouble I have seen: A history of violence against wives. Cambridge, MA: Harvard University Press.

Delgado, R. (1982). Words that wound: A tort action for racial insults, epithets, and name-calling. Hard Civil Rights-Civil Liberties Law Review, 17, 133.

Delgado, R., \& Stefancic, J. (2001). Critical race theory: An introduction. New York: New York University Press. 
Devine, D. (2008). Naming the 'other': Children's construction and experience of racisms in Irish primary schools. Race, Ethnicity \& Education, 11, 369-385.

Du Bois, W. E. B. (2005). The souls of black folk. New York: Barnes and Noble Classics. Originally published in 1903.

Dyer, R. (1993). The matter of images: Essays on representations. London: Routledge.

Eastwood, C. (Director) \& Kaufman, P. (Writer). (1976). The Outlaw Josey Wales (Motion Picture). United States: Warner Brothers.

Francis, D. (1995). The imaginary Indian: The image of the Indian in Canadian culture (3rd ed.). Vancouver, Canada: Arsenal Pulp Press.

Gallagher, M. (2001). Gender setting: New agendas for media monitoring and advocacy. London: Zed Books.

Gallagher, M. (2006). Feminist media perspectives. In A. N. Valdivia (Ed.), A companion to media studies (pp. 19-39). Walden, MA: Wiley-Blackwell.

Goings, K. W. (1994). Mammy and Uncle Mose: Black collectibles and American stereotyping. Bloomington: Indiana University Press.

Gordon, L. (1995). Bad faith and antiblack racism. Atlantic Highlands, NJ: Humanities Press.

Green, M. K. (1993). Images of American Indians in advertising: Some moral issues. Journal of Business Ethics, 12, 323-330.

Green, R. (1975). The Pocahontas perplex: Images of Indian women in American culture. The Massachusetts Review, 16, 698-714.

Guedel, G. (2009, May 11). Homicide now a top-10 cause of death for Native American women. Native American Legal Update. Retrieved June 2, 2009, from http://www.nativelegalupdate.com/2009/05/articles/homicide-now-a-top10cause-of-death-for-native-american-women

Gunn Allen, P. (1986). The sacred hoop: Recovering the feminine in American Indian traditions. Boston: Beacon.

Hagengruber, J. (2006, October 6). Tribe wants ‘squaw' off map. Spokesman Review. Retrieved July 1, 2008, from http://www.spokesmanreview.com/idaho/story. asp?ID $=153172$ \&page $=$ all

Henry, F., \& Tator, C. (2002). Discourses of domination: Racial bias in the Canadian English-language press. Toronto: University of Toronto Press.

Hernández-Avila, I. (2005). Reading Native American women: Critical/creative representations. Lanham, MD: AltaMira.

Johnston, C. B. (2000). Screened out: How the media control us and what we can do about it. New York: M. E. Sharpe.

Jonas, T. (2003). The controversy over the word 'squaw.' Retrieved April 10, 2008, from www.tomjonas.com/squawpeak/squaw.htm

Keller, G. D. (1994). Hispanics and United States film: An overview and handbook. Tempe, AZ: Bilingual Review/Press.

Kessler, D. J. (1996). The making of Sacagawea: A Euro-American legend. Tuscaloosa: University of Alabama Press.

La Duke, W. (1999). All our relations: Native struggles for land and life. Boston: South End Press.

La Duke, W. (2005). Foreword. In A. Smith (Ed.), Conquest: Sexual violence and American Indian genocide (pp. xv-xviii). Boston: South End Press. 
Lang, R. (Director). (1980). The Mountain Men (Motion Picture). United States: Columbia Pictures Corporation.

Lindley, S. H. (1996). 'You have stept out of your place': A history of women and religion in America. Peabody, MA: Westminster John Knox Press.

Marubbio, M. E. (2006). Killing the Indian maiden: Images of Native American women in film. Lexington: University Press of Kentucky.

McBride, B. A. (2003). Aspects of community healing: Experiences of the Sault Sainte Marie tribe of Chippewa Indians. American Indian \& Alaska Native Mental Health Research: The Journal of the National Center, 11(1), 67-83.

McHoul, A., \& Grace, W. (1997). A Foucault primer: Discourse, power and the subject. New York: New York University Press.

McKinlay, A., \& Potter, J. (1987). Model discourse: Interpretative repertoires in scientists' conference talk. Social Studies of Science, 17(3), 443-463.

McRobbie, A. (1997). 'Bridging the gap': Feminism, fashion, and consumption. Feminist Review, 55, 73-89.

Merskin, D. (1998). Sending up signals: A survey of Native American media use and representation in mass media. Howard Journal of Communications, 9, $333-345$.

Merskin, D. (2001). Winnebagos, Cherokees, Apaches, and Dakotas: The persistence of stereotyping of American Indians in American advertising brands. Howard Journal of Communication, 12, 159-169.

Merskin, D. (2008). Three faces of Eva: Perpetuation of the Hot-Latina stereotype in Desperate Housewives. Howard Journal of Communications, 18, 133-151.

Mihesuah, D. A. (2003). Indigenous American women: Decolonization, empowerment, activism. Lincoln: University of Nebraska Press.

Monmonier, M. (2006). From Squaw Tit to Whorehouse Meadow: How maps name, claim, and inflame. Chicago: University of Chicago Press.

Nagel, J. (2000). Ethnicity and sexuality. Annual Review of Sociology, 26, 107-133.

Neumann, K. (Director). (1956). Mohawk (Motion Picture). United States.

Newton, J. A. (2000). The burden of visual truth. Newbury Park, CA: Sage.

Norden, T. (1996). Fawn Stubben: Heritage hero. Goldfinch, 18(1), 5-7.

Perry, B. (2002). From ethnocide to ethno violence: Layers of Native American victimization. Contemporary Justice Review, 5, 231-247.

Pflüg, M. A. (1996). 'The last stand'? Odawa revitalizationists versus U.S. Law. In D. Westerlund (Ed.), Questioning the secular state: The worldwide resurgence of religion in politics (pp. 75-95). London: C. Hurst \& Co.

Ramíerez-Berg, C. (1990). Latino images in film: Stereotypes, subversion, resistance. Austin: University of Texas Press.

Reese, D. (2007, October 22). The word 'squaw' in sign of the beaver. American Indians in Children's Literature. Retrieved July 24, 2008, fromhttp://americanindiansinchildrensliterature.blogspot.com/2007/10/word-squaw-in-sign-of-beaver. html

Richardson, L., \& Adams St. Pierre, E. (2000). Writing: A method of inquiry. In N. K. Denzin \& Y. S. Lincoln (Eds.), Handbook of qualitative research (pp. 923-948). Thousand Oaks, CA: Sage.

Ross, H. (2000, August). Lifting the unequal burden of cancer on minorities and the underserved: NCI develops strategic plan to reduce cancer related health 
disparities. Washington, DC: Office of Minority Health, U.S. Department of Health and Human Services.

Sanchez, J. (2003). How American public schools using down-linked news media shape American Indian identity. Howard Journal of Communications, 14, 39-48.

Sanders, E. (2004, December 11). Renaming 'squaw' sites proves touchy in Oregon. New York Times, p. A12.

Sanders, T. E., \& Peek, W. W. (1973). Literature of the American Indian. New York: Glencoe.

Schroeder, J. E., \& Borgerson, J. L. (2005). An ethics of representation for international marketing communication. International Marketing Communication, 22, 578-600.

Schroeder, J. E., \& Borgerson, J. L. (2008). Building an ethics of visual representation: Contesting epistemic closure in marketing communication. In M. PainterMorland \& P. Werhane (Eds.), Cutting-edge issues in business ethics (pp. 88-107). New York: Springer.

Seals, D., \& Young, J. (2003). Bullying and victimization: Prevalence and relationship to gender, grade level, ethnicity, self-esteem, and depression. Adolescence, 38, $735-747$.

Silvern, S. E. (2002). Place names and the politics of indigenous identities. Retrieved June 2, 2009, from http://www.pacificworlds.com/ipsg/aagweb02/Silvern.htm

Smith, A. B. (2000). Shooting cowboys and Indians: Silent western films, American culture, and the birth of Hollywood. PhD dissertation, University of California Los Angeles.

Smits, D, D. (2007). The squaw drudge. In R. Kugel \& L. Eldersveld Murphy (Eds.), Native women's history in Eastern North America before 1900: A guide to research and writing (pp. 27-49). Lincoln: University of Nebraska Press.

Speare, E. G. (1983). The sign of the beaver. New York: Bantam.

Oxford English Dictionary, 2nd ed. [Online]. (1989). Retrieved January 7, 2010 from http://0dictionary.oed.com.janus.uoregon.edu/cgi/entry/50235256?single=1\&query_type $=$ word $\&$ queryword $=$ squaw $\&$ first $=1 \&$ max_to_show $=10$

Stubben, J. D., \& Sokolow, G. (2005). Native Americans and political participation: A reference handbook. Santa Barbara, CA: ABC-Clio.

Sundquist, A. (1987). Pocahontas \& co.: The fictional American Indian woman in nineteenth-century literature, a study of method. Oslo, Norway: Solum Forlag $\mathrm{A} / \mathrm{S}$.

Sundquist, A. (1991). Sacagawea \& Co.: The twentieth century fictional American Indian woman and fellow characters, a study of gender and race. Oslo, Norway: Solum Forlag A/S.

Tafoya, N. (2005). Native American women: Fostering resiliency. In M. Pravder Mirkin, K. L. Suyemoto, \& B. F. Okun (Eds.), Psychotherapy with women: Exploring diverse contexts. New York: Guilford.

Terry, F. (1897, March). Naming the Indians. American Monthly Review of Reviews. Retrieved June 2, 2009, from http://www.webroots.org/library/usanativ/ tfnti000.html

Tessier, M. (2008, July 25). Intimate violence remains a big killer of women. Women's e-news. Retrieved June 2, 2009, from http://www.womensenews. org/article.cfm/dyn/aid/3683 
Tuchman, G. (1978). The symbolic annihilation of women by the mass media. In G. Tuchman, A. C. Daniels \& J. Benét (Eds.), Hearth and home: Images of women in the media (pp. 3-38). New York: Oxford University Press.

The unequal burden of cancer: An assessment of NIH research and programs for ethnic minorities and the medically underserved. (1999). Washington, DC: Institute of Medicine, National Academy Press.

U.S. Geological Survey. (2008). Retrieved August 4, 2008, from http://geonames. usgs.gov

Valaskakis, G. G. (2005). Indian country. Waterloo, ON, Canada: Wilfrid Laurier Univ. Press.

Vannoy Adams, M. (1985). Deconstructive philosophy and imaginal psychology: Comparative perspectives on Jacques Derrida and James Hillman. Journal of Literary Criticism, 2(1), 23-39.

Walker, M. U. (1998). Moral understandings: Feminist studies in ethics. New York: Routledge.

Walters, K. L., \& Simoni, J. M. (2002). Reconceptualizing Native women's health: An 'indigenist' stress-coping model. American Journal of Public Health, 92, 520-524.

Watner, C., \& McElroy, W. (2004). National identification systems: Essays in opposition. Jefferson, NC: McFarland. 
Copyright of Howard Journal of Communications is the property of Routledge and its content may not be copied or emailed to multiple sites or posted to a listserv without the copyright holder's express written permission. However, users may print, download, or email articles for individual use. 